\title{
Managing resources and innovation inside the industry (Industrial) 4.0 Revolution: The role of Supply Chain ${ }^{1}$

\author{
Niccolò Fiorini - Matteo Devigili - Tommaso Pucci \\ Lorenzo Zanni
}

\begin{abstract}
Purpose of the paper: On the lights of Resource Based View (RBV), this research aims to analyse the impact of resources on Process Innovation (PI) in the context of Industry 4.0 (I4.0), thus proposing stimuli coming from Supply Chain (SC) as moderator of this relationship.

Methodology: Our conceptual model was tested on a sample of 115 Italian firms and data were collected through a structured survey submitted to purchasing and buyer agents/managers.

Results: The econometric analysis shows a positive impact of resources 4.0 on PI, and horizontal stimuli coming from SC (Competitors, Universities, Consultants, and Technology Transfer Offices) were found to positively moderate this relationship. Moreover, post-hoc analysis shows that firms can obtain higher PI outcomes combining the exploitation of horizontal 4.0 stimuli with changes on BM.

Research limitations: This research presents three main limitations: (i) geographic location, all firms are Italian; (ii) timing, it assesses I4.0 in an early stage for the Italian entrepreneurial ecosystem; (iii) moderate sample size.

Practical implications: This study contributes to the understanding of both academic and practitioners of the impact of I4.0 on SC, trying to grasp not only the effect of internal resources but also of external stimuli.

Originality of the paper: To the best of our knowledge this paper is the first one analysing the impact of I4.0 stimuli on SC. Moreover, the survey involved a relevant number of on-field experts in comparison to similar studies on Supply Chain and I4.0 effects.
\end{abstract}

Key words: industry 4.0; supply chain; innovation; technological resources; business model

\section{Introduction}

I4.0 has been a trend topic over the last few years, reaching almost a thousand works published in 2017 (see Figure 1). Moreover, as Table 1 highlights, this research topic has engaged the academic attention from several disciplines, such as engineering, computer science, business and so forth (see also: Kang et al., 2016; Hermann et al., 2016 and Liao et al., 2017).

1 The authors would like to thank ADACI and all its members for their fruitful collaboration in conducting this survey. 
sinergie

Vol. 37, Issue 2, 2019
Fig. 1: Works on Industry 4.0

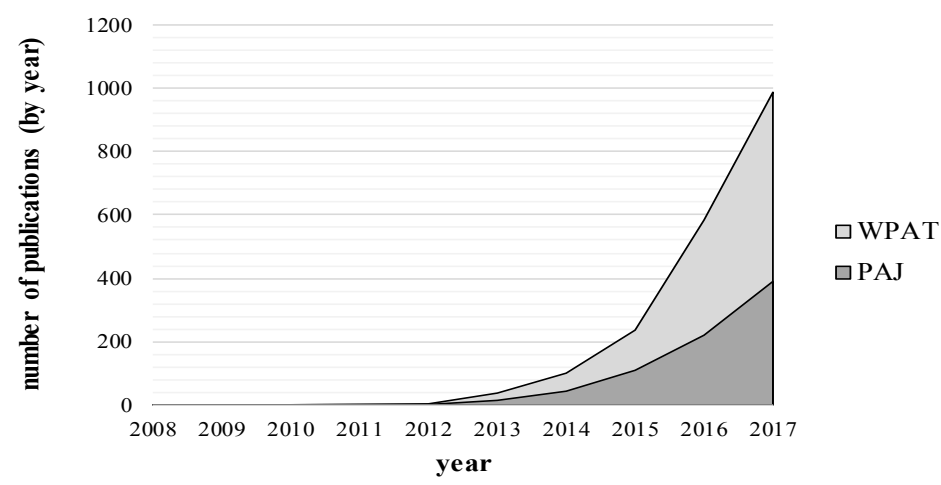

Source: SCOPUS, January 2008-December 2017

Research strategy: "Industry 4.0" OR "Industrie 4.0" in "Title, Abstract, and Keywords".

This area graph shows trends in the number of Industry 4.0 articles. WPAT $=$ works published in all document types; PAJ $=$ articles published in academic journals.

Tab. 1: subject areas of works on Industry 4.0

\begin{tabular}{|l|c|c|}
\hline Subject Area & No. & $\%$ \\
\hline Engineering & 583 & $74,84 \%$ \\
\hline Computer Science & 224 & $28,75 \%$ \\
\hline Business, Management and Accounting & 179 & $22,98 \%$ \\
\hline Materials Science & 134 & $17,20 \%$ \\
\hline Decision Sciences & 116 & $14,89 \%$ \\
\hline Chemistry & 49 & $6,29 \%$ \\
\hline Social Sciences & 44 & $5,65 \%$ \\
\hline Physics and Astronomy & 40 & $5,13 \%$ \\
\hline Chemical Engineering & 25 & $3,21 \%$ \\
\hline Energy & 23 & $2,95 \%$ \\
\hline Mathematics & 23 & $2,95 \%$ \\
\hline Economics, Econometrics and Finance & 18 & $2,31 \%$ \\
\hline Environmental Science & 12 & $1,54 \%$ \\
\hline Arts and Humanities & 10 & $1,28 \%$ \\
\hline Biochemistry, Genetics and Molecular Biology & 7 & $0,90 \%$ \\
\hline Earth and Planetary Sciences & 6 & $0,77 \%$ \\
\hline Agricultural and Biological Sciences & 5 & $0,64 \%$ \\
\hline Pharmacology, Toxicology and Pharmaceutics & 4 & $0,51 \%$ \\
\hline Medicine & 3 & $0,39 \%$ \\
\hline Psychology & 2 & $0,26 \%$ \\
\hline Neuroscience & 1 & $0,13 \%$ \\
\hline
\end{tabular}

Note: The sum is not $100 \%$ because works overlap different subject areas

Source: Our elaboration 
This interest is stimulated by the pervasive ability of I4.0 to integrate and merge the digital and virtual world both vertically and horizontally (Ghobakhloo, 2018). Indeed, we can consider I4.0 as a further step towards the digitalization of the manufacturing sector, driven by the (i) rise of available data, (ii) improvement of analytics and business-intelligence, (iii) enhancement of human-machine interaction, and (iv) progress in transmitting digital instructions to the non-digital reality (Sung, 2018). However, while technical aspects and the impacts of I4.0 technologies have been broadly discussed analytically, there is still need for both theoretical and empirical studies (Ben-Daya et al., 2017; Bienhaus and Haddud, 2018).

The term Industrie 4.0 (Industry 4.0) and its paradigms were designed in Germany (Kagermann et al., 2013) to secure the future of the national manufacturing industry. The design and implementation processes were linked and supported by the "HightechStrategie" (HTS) plan launched by the German Ministry of Education and Research (Horst and Santiago, 2018). Following the German attempt, other countries introduced their own I4.0 plans: the UK ("UK Catapult - High Value Manufacturing"), USA ("Manufacturing USA", 2014), France ("Industrie du Futur", future industry, 2015), The Netherlands ("Smart Industry", 2014), and Italy ("Piano Nazionale Industria 4.0", National Plan on industry 4.0, 2016). Nevertheless, the leading role of Germany on I4.0 emerges also at a research level, where this country authors (i) account for almost the $40 \%$ of the total work published and (ii) gain a central position in the international research scene as the most cited (see figure 2). Other countries extensively dealing with I4.0 are China, Italy, Spain, the US and the UK.

While differing in introduction and development policies, all the national plans aiming to introduce I4.0 focus on the same technologies and paradigms. However, scholars have not been able to reach a shared definition about I4.0, offering a noticeable variety of them (Bittighofer et al., 2018), which were more than 100 until 2016 (Bidet-Mayer andCiet, 2016). This is why Pereira and Romero (2017) defined I4.0 as an "umbrella term" for a new paradigm regarding future industrial developments renouncing to identify a sole definition of I4.0.

2 The "Piano Nazionale Industria 4.0" (PN4.0), also called "Piano Calenda" from the surname of the Ministry of economic development who promoted it, was presented for the first time in Milan in September 2016. It involved the government, some universities, some nation-wide research centres, some industrial organisations, as well as trade unions and the Italian investment bank CDP Spa. The PN4.0 aims to encourage investments in innovation as well as competencies. It helps companies in acquiring I4.0 technologies via tax breaks, and innovative start-ups to design I4.0 business thanks to venture capital financing. Moreover, there is help also coming from universities and research centres which are requested to perform researches in the I4.0 field. Several "Digital Innovation Hubs" (DIH) play the role of dissemination, technology transfer and help for companies and organisations. Moreover, the "Competence Centres 4.0" (CC4.0) are in charge of I4.0 formation, launch and participation in innovative processes (both at local, national and international level), and field testing. (www.mise.gov.it).
Niccolò Fiorini

Matteo Devigil

Tommaso Pucci

Managing resources and nnovation inside the industry (Industrial) 4.0 Revolution: The role of Supply Chain 


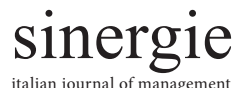

Vol. 37, Issue 2, 2019
Fig. 2: Countries

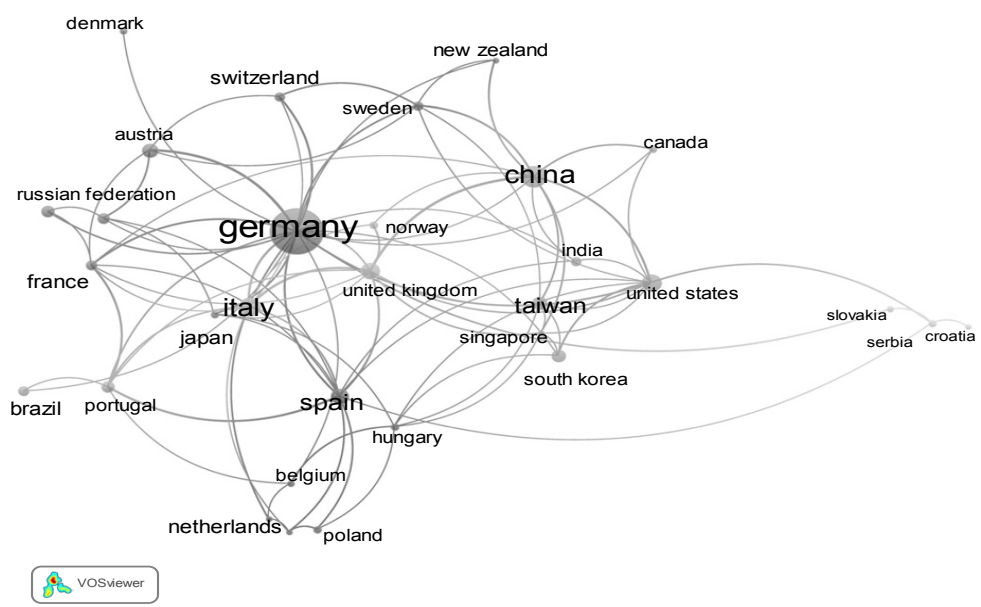

Source: SCOPUS, January 2008-December 2017

Research strategy:"Industry 4.0" OR "Industrie 4.0" in "Title, Abstract, and Keywords".

Nevertheless, analysing technical details of the fourth industrial revolution, we understand that I4.0 bases its pillars on existing technologies rather than on new ones: the difference relies on the exploitation of those technologies (Baur and Wee, 2015). For example, according to Schmidt et al. (2015) big data and cloud computing are driving forces for I4.0, but those technologies have already been used in several other contexts and for different applications (Drath and Horch 2014). Therefore, superior benefits come from a more integrated connectivity of all the actors and factors involved along the whole chain. Some scholars underline the important trend leading to the integration between physical and virtual spaces ( $\mathrm{Li}$ $\mathrm{Da} \mathrm{Xu}$ et al., 2018), especially in manufacturing sectors. Indeed, not only machines, but also products, data, "things" and humans are connected according to the new I4.0 paradigms (see among the others: Kang et al., 2016; Lin et al., 2017; Lu, 2017; Wahl, 2015), thus leading to a necessary rethinking and reorganization of the whole industrial processes (Hermann et al. 2016). However, connection affects not only production systems, being the cornerstone for new organizational structures (Fantoni et al. 2017b), but also the value chain as a whole, especially in manufacturing industries (Rüßmann et al., 2015). Indeed, according to Schrauf and Berttram (2016), the digital supply chain is the core of all the activities 4.0 implemented in the ecosystem, and in the near future, always more actors will count on digitised horizontal and vertical value-chain processes (Geissbauer et al., 2016). Indeed, this adoption process of technologies and methods 4.0 aiming at both integration and interconnection of the SC, is also visible at regional level (Bertini, 2017). This careful attention paid to integration and interconnection is due to the fact that Integrative Technologies, such as Big Data, Internet of Things, and Additive Manufacturing, are considered core driving forces to increase profitability and competitiveness modifying SC outline through interconnectivity (Bucy et al., 2016; Zhong et al., 2016), 
or to grasp advantages from synergies based on customisation (Kumar et al., 2016). Hence, starting from the enabling technologies individuated by the "Piano Nazionale 4.0 " and by the literature above concerning the I4.0 paradigm, we defined the following technologies as Resources 4.0: advanced manufacturing solutions, additive manufacturing, augmented reality, simulation, horizontal/vertical integration, industrial internet, blockchain, cloud, cyber-security, big data and analytics.

Recently, the I4.0 Paradigm has also captured the attention of SC literature, thus investigating the effect of 4.0 technologies on SC management (see among other: Tjahjono et al., 2017, Ben-Daya et al., 2017). Indeed, implementing I4.0 on SC may enhance flexibility, quality standards, efficiency, productivity, and product customization (Tjahjono et al., 2017). However, to the best of our knowledge, no significant research has been conducted to understand the impact, attitude, and behaviour of all the SC actors towards new I4.0 resources. Furthermore, employing VosViewer, we performed a bibliometric analysis of 778 articles1, thus obtaining Figure 3 that shows the presence of SC theme in the I4.0 literature, emphasising also its peripheral position.

Fig. 3: Works density

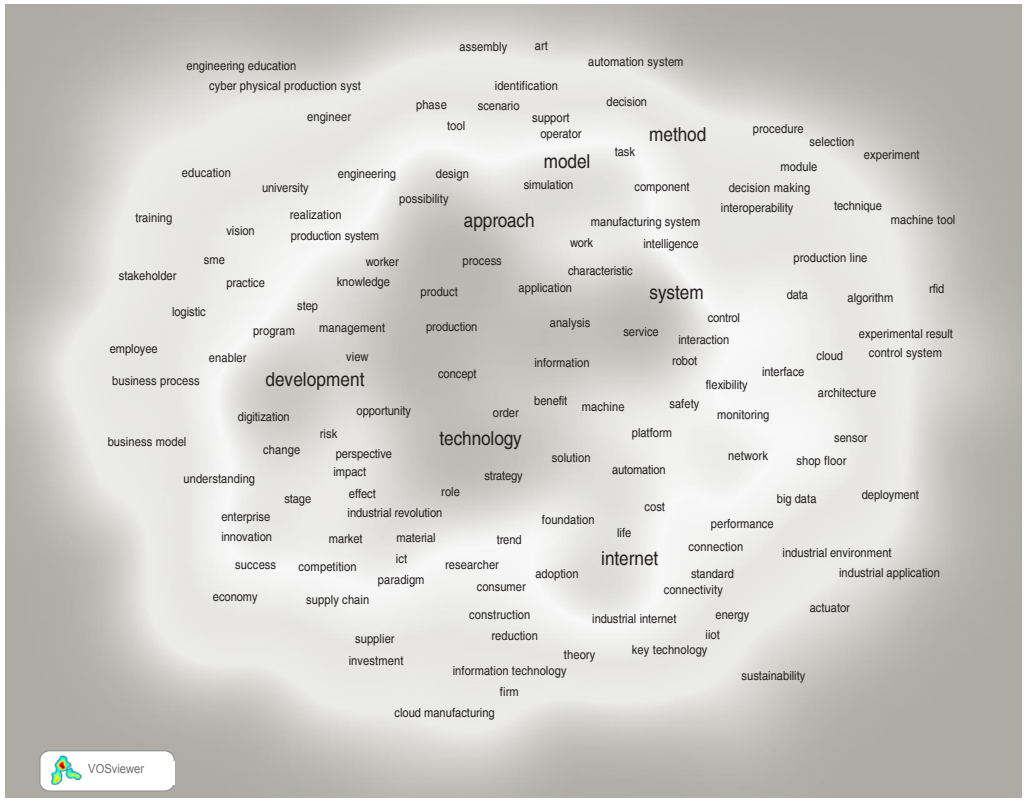

Source: SCOPUS, January 2008-December 2017

Research strategy: "Industry 4.0" OR "Industrie 4.0" in "Title, Abstract, and Keywords"

Therefore, much more investigations are needed to grasp richer insights on this phenomenon in order to investigate linkages and influences among SC and the most I4.0 core topics (see also: Kersten and Blecker, 2015).

Furthermore, from the literature emerges that I4.0 will not only impact on products but also on the design and manufacturing processes (Tjahjono 
sinergie Vol. 37, Issue 2, 2019

et al., 2017; Ghobakhloo, 2018). Indeed, the innovation of firms' processes is crucial to gain both productivity and efficiency improvements, and an effective competitive advantage (Terjesen and Patel, 2017; Trantopoulos et al., 2017). However, given "the complexity of identifying, developing, and implementing process innovations" (Terjesen and Patel, 2017, p. 1421), firms should rely on external sources such as SC actors (Trantopoulos et al., 2017). This is also due to the fact that I4.0 technologies, by integrating services and guaranteeing access to industrial ecosystem's information, offer a significant contribution to all the partners of the SC ( $\mathrm{Li} \mathrm{Da} \mathrm{Xu}$ et al., 2018). Moreover, I4.0 has a positive impact in process optimisation (i.e. in PI) during the engineerization process thanks to virtual simulations (Müller et al., 2018). Furthermore, scholars point out not only the importance of I4.0 for product development, but also indicate the crucial role of I4.0 in increasing, optimising and, more generally, positively affecting processes in the whole SC (see, among others, Pereira and Romero, 2017 and Popkova et al., 2019). Even though I4.0 affects both process and product innovation, focusing on the SC, I4.0 significantly affects mainly the processes (Lin et al., 2017, and Fernández-Miranda et al. 2017). Among several positive influences of I4.0 on SC in terms of PI, some authors underline flexibility, greater communication and efficiency (among others, see: Ding, 2018, and Dalenogare et al., 2018), while Kovács and Kot (2016) point out PI effects on logistics as a whole. Hence, when considering SC and I4.0 we believe it is relevant to focus our attention on I4.0 impact on PI.

Unfortunately, not only PI literature lacks quantitative analysis (Trantopoulos et al., 2017) and a conclusive understanding of PI's antecedents (Keupp et al., 2011; Terjesen and Patel, 2017), but also the research on the impact of I4.0 on PI is still scarce and fragmented.

Therefore, to enhance the discussion over these literature gaps, this research relies on the resource-based view (RBV) approach (Barney, 1991; Armstrong and Shimizu, 2007). Indeed, it is widely recognized that both internal resources (and capabilities) and external sources are able to affect firms' innovation, alone or jointly (Arora and Gambardella, 1994; Veugelers and Cassiman, 1999; Caloghirou et al., 2004; Di Stefano et al., 2012). Therefore, understanding (i) how resources are internally exploited according to the new I4.0 paradigm and (ii) what is the impact of external stimuli on PI, will promote a deeper understanding of Supply Chain 4.0 (SC4.0). Hence, from the perspective of internal firm resources, we aim to investigate the following research question: (RQ1) What is the impact of Resources 4.0 on PI?

From the perspective of external sources coming from suppliers, partners, and customers (Thomke and Von Hippel, 2002; Von Hippel, 2007) or from the "environment" (e.g. institutions. Lee et al., 2001), we considered the impact of what we defined Stimuli 4.0 coming from SC. Based on Trantopoulos et al. (2017) we individuated the possible players bringing innovation in the SC (i.e. suppliers of materials, suppliers of machineries, suppliers of software, customers B2B, customers B2C, distributors/trade, competitors, university and public research centres, consultants, and technological transfer offices), whose impact was evaluated by interviews, and that were then divided, through factor analysis, into upstream, 
downstream and horizontal sources. Hence, we want to understand: (RQ2) What is the role of stimuli 4.0 coming from SC on PI?

Lastly, a key strength of this research concerns the target respondent of the survey, namely purchasing and buyer agents/managers. Indeed, since this category plays a significant role in the development and procurement of resources, they are expected to have a substantial stake in the acquisition of key 4.0 resources. Therefore, thanks to the valuable collaboration of $\mathrm{ADACI}^{3}$, we were able to gather data from a consistent panel of on-field experts.

The article is organized as follows: Section 2 discusses the theoretical framework, the conceptual model, and the research hypothesis; Section 3 outlines the sample characteristics, variables operationalization, and empirical methodologies; Sections 4 presents and discusses the findings; Section 5 draws some conclusions and discusses possible limitations and further research topics.

\section{Theoretical Background and Conceptual Model}

Considering the theoretical background exposed in the previous section, and looking at the origin of resources in a deeply interconnected and mutating environment, an internal/external investigation of resources' flows (Kogut and Zander, 1992 and Wahl, 2015) will allow a deeper understanding of the mutual influences exerted by actors involved in the SC4.0.

For what concerns the internal perspective, RBV theory stresses the importance of resources as they grant a competitive advantage to the company owing them thanks to their value, rareness, inimitability, and sustainability (Barney, 1991; Grant, 1991; Barney, 2001). However, firms are borderless in the SC, having both inter-organizational relationships as well as integrated business processes, (Halldórsson et al., 2015; Zanni and Pucci, 2012). Thus, the RBV theory applied to SC4.0 should be analysed under a more flexible lens, admitting (i) the coexistence of different boundaries (Carlile, 2004) and (ii) the twofold impact of resources 4.0 coming both from inside the firm and from other SC actors. However, we should still define what we mean by "I4.0 resources". The current literature has highlighted several technologies enabling I4.0 and deeply influencing the firms' processes and production (Kreipl and Pinedo, 2004; Carbonneau et al., 2008; Sahay and Ranjan, 2008; Visich et al., 2009; Gebbers and Adamchuk, 2010; Lopez et al., 2012; Maslarić et al., 2016; Tian, 2016; Nakasumi, 2017; Wamba et al., 2008; Witkowski, 2017; Majeed and Rupasinghe, 2017; Barreto et al., 2017; Khaqqi et al., 2018), thus bringing disruptive changes to the whole SC ( $\mathrm{Lu}, 2017)$, and

ADACI, Associazione Italiana Acquisti e Supply Management (Italian Association for Purchasing and Supply Chain Management) is the leading Italian association for procurement and supply chain management. Founded in 1968, ADACI is also the founder of the International Federation of Purchasing and Supply Management (IFPSM), the union of 48 National and Regional Purchasing Associations worldwide (sources: https://www.adaci.it and http:// www.ifpsm.org/).
Niccolò Fiorini

Matteo Devigili Tommaso Pucci Lorenzo Zanni

Managing resources and innovation inside the industry (Industrial) 4.0 Revolution: The role of Supply Chain 
sinergie Vol. 37, Issue 2, 2019

fostering SC progress (Witkowski, 2017). Among the other, they underline: advanced manufacturing solutions, additive manufacturing, augmented reality, simulation, horizontal/vertical integration, industrial internet, cloud, cyber-security, blockchain, big data and analytics. Given these theoretical bases, our first research hypothesis is: (Hp.1) the procurement and development of resources linked with the I4.0 paradigm has a positive impact on the PI of a firm.

For what concerns the external perspective, while Trantopoulos et al. (2017) focused on firms search for external stimuli, this inquiry aims to reverse the perspective looking for external stimuli influencing firm's process innovation.

The new SC4.0 is completely integrated, coordinated and controlled using an ICT platform (Atti, 2018b), and it has become a crystalline integrated ecosystem (Schrauf and Berttram, 2016). Moreover, Atti (2018b) states that the SC4.0 helps the co-creation and co-innovation thanks to the integration of procurement. The supply network structure of independent but well-connected actors looks after a collaborative advantage for everyone in the chain (Chen and Paulraj, 2004). Indeed, the integration among different firms of the SC is both horizontal (with Universities, Consultants, Technology Transfer Offices etc.), within the value chain, and vertical (with Suppliers, Customers, Distributors etc.), with linkages aiming to increase performances for outward-facing firms (Frohlich and Westbrook, 2001). Moreover, since the literature underlined how external sources, which might be vertically or horizontally linked with the company, are able to influence the adoption of innovations (Terjesen and Patel, 2017; Trantopoulos et al., 2017), a similar result should be expected also in the case of 4.0 resources. Hence, we believe that stimuli coming from other players in the SC are able to moderate the effect of resources 4.0 on PI. Therefore, our second hypothesis is: (Hp.2) stimuli 4.0 coming from the SC are able to positively moderate the impact of the Resources 4.0 on PI.

Our research questions and hypothesis are visually summarized in Figure 4, thus showing our conceptual model.

Fig. 4: Conceptual Model

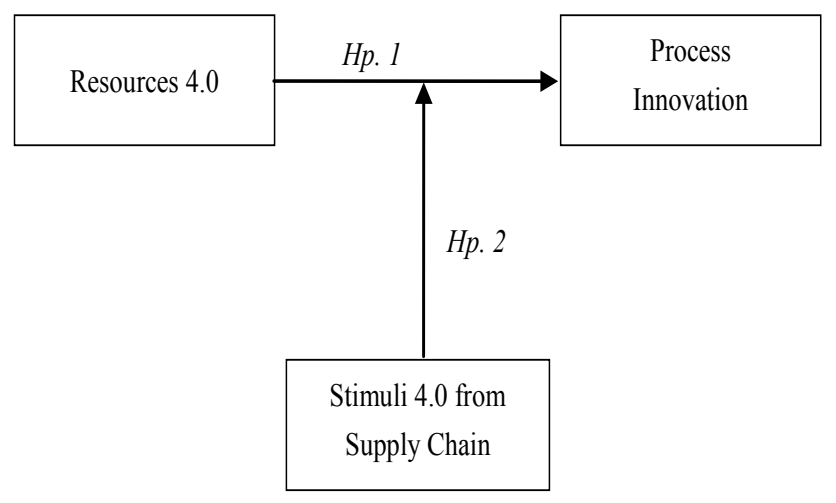

Source: Our elaboration 


\subsection{Data Collection}

Managing resources and

innovation inside the

industry (Industrial) 4.0

Data were collected through a survey submitted both online and offline from July to October 2018 to Italian firms.

For what concerns the online channel, the e-mail survey was submitted to 467 firms obtaining 31 usable answers (redemption rate of 6, 64\%). A presentation letter, outlining both research objectives and privacy information, was attached to each e-mail. For what concerns the offline channel, the research team attended several Conferences and Workshops organized by ADACI (Italian association for purchase and supply management), distributing the questionnaire directly to purchasing and buyer agents/managers, thus collecting 93 answers. Of these responses, 9 did not specify the company name, consequently were excluded. Data concerning the number of employees and years from the constitution were then gathered through secondary sources, namely the Chamber of Commerce. Therefore, we obtained 115 usable answers from: 33 Micro firms (employees < 10), 34 Small $(10 \leq$ employees $<50), 31$ Medium $(50 \leq$ employees $<250$ ), and 17 Large firms (employees $\geq 250$ ). Respondents are mainly located in the north of Italy (62\%).

\subsection{Measures}

The variables here presented are outlined in table 2, thus showing items description and Cronbach alpha when necessary.

Dependent Variable: Process Innovation is the outcome variable of our analysis and was measured through a multi-item construct developed by the research team, starting from Terjensen and Patel (2017). Firms were asked to state if they had introduced systems improvements concerning (1) supply, (2) storage, (3) production, (4) distribution, or (5) sale and post-sale in the last three years. Each item was operationalized as a dummy where 0 stands for not introduced, while 1 for introduced. Consequently, the PI variable was operationalized as the arithmetic mean of the five items.

Independent Variables: Resources 4.0 was operationalized starting from the Piano Calenda (2016). Firms were asked to state if they had introduced one or more of the following resources in the last three years: (a) advanced manufacturing solutions, (b) additive manufacturing, (c) augmented reality, (d) simulation, (e) horizontal/vertical integration, (f) industrial internet, (g) blockchain, (h) cloud, (i) cyber-security, (l) big data and analytics. Each item was operationalized as a dummy where 0 stands for not introduced, while 1 for introduced. Consequently, the Resources 4.0 variable was operationalized as the arithmetic mean of the 10 items. Stimuli 4.0 from Supply Chain was adapted from Trantopoulos et al. (2017), thus distinguishing among 10 possible players acting as sources of innovation: [1] suppliers of materials, [2] suppliers of machineries, [3] suppliers of software, [4] customers B2B, [5] customers B2C, [6] distributors/trade, [7] competitors, [8] university and public research centres, [9] consultants, and [10] technological transfer offices. Then, firms were asked to evaluate the 
sinergie italian journal of management Vol. 37, Issue 2, 2019 impact held by each actor on their learning process regarding Industry 4.0, from 1 "no impact" to 5 "high impact". Finally, through factor analysis, we obtained three variables merging [1], [2], and [3] in upstream sources, [4], [5], and [6] in downstream sources, and [7], [8], [9], and [10] in horizontal sources. The reliability test over these three constructs provided satisfactory results, showing Cronbach's alphas greater than 0, 7 (Hair et al., 2010).

Tab. 2: Measures description

\begin{tabular}{|c|c|c|}
\hline Variables & Items & $\begin{array}{c}\text { Cronbach's } \\
\alpha\end{array}$ \\
\hline Process Innovation & & - \\
\hline (dummy, 1 = "selected") & Technological improvements to supply systems & \\
\hline $\begin{array}{l}\text { Source: our processing and adaptation starting } \\
\text { from }\end{array}$ & $\begin{array}{l}\text { Technological improvements to storage systems } \\
\text { (incoming logistics) }\end{array}$ & \\
\hline \multirow[t]{3}{*}{ Terjensen and Patel, 2017} & $\begin{array}{l}\text { Technological improvements to production } \\
\text { systems }\end{array}$ & \\
\hline & $\begin{array}{l}\text { Technological improvements to distribution } \\
\text { systems (outbound logistics) }\end{array}$ & \\
\hline & $\begin{array}{l}\text { Technological improvements to sales and after- } \\
\text { sales processes }\end{array}$ & \\
\hline Resources 4.0 & & - \\
\hline (dummy, 1 = "selected") & Advanced Manufacturing Solutions & \\
\hline \multirow[t]{9}{*}{ Source: Piano Calenda, 2015} & Additive Manufacturing & \\
\hline & Augmented Reality & \\
\hline & Simulation & \\
\hline & Horizontal/Vertical Integration & \\
\hline & Industrial Internet & \\
\hline & Blockchain & \\
\hline & Cloud & \\
\hline & Cyber-security & \\
\hline & Big Data and Analytics & \\
\hline \multicolumn{3}{|l|}{ Stimuli 4.0 from Supply Chain } \\
\hline (likert scale 1-5) & Upstream & 0,727 \\
\hline $\begin{array}{l}\text { Source: our processing and adaptation starting } \\
\text { from }\end{array}$ & Suppliers (materials) & \\
\hline \multirow[t]{11}{*}{ Trantopoulos et al., 2018} & Suppliers (machinery) & \\
\hline & Suppliers (software) & \\
\hline & Downstream & 0,730 \\
\hline & Customers (B2B) & \\
\hline & Customers (B2C) & \\
\hline & Distributors/Trade & \\
\hline & Horizontal $\quad 0,800$ & \\
\hline & Competitors & \\
\hline & $\begin{array}{l}\text { Universities and Public or Private Research } \\
\text { Centres }\end{array}$ & \\
\hline & Consultants & \\
\hline & Technological Transfer Offices & \\
\hline \multicolumn{3}{|l|}{ Control variables } \\
\hline $\begin{array}{l}\text { (Natural logarithm of the number of years since } \\
\text { the constitution) }\end{array}$ & Age (log) & - \\
\hline (Natural logarithm of the number of employees) & Size $(\log )$ & - \\
\hline (Percentage of foreign sales on total turnover) & Foreign sales & - \\
\hline $\begin{array}{l}\text { (Percentage of R\&D expenditure on total } \\
\text { turnover) }\end{array}$ & R\&D expenditures & - \\
\hline (dummy, 1 = "selected") & Busin. Model Innovat. & - \\
\hline
\end{tabular}

Source: Our elaboration 
Control Variables: To reliably test the relationship among dependent and independent variables and to control for endogeneity, we introduced several control variables able to influence PI. We employed the natural logarithm of (i) the number of years since the constitution and (ii) the

number of employees, to control respectively the firm's Age and Size, Managing resources and nnovation inside the industry (Industrial) 4.0 Revolution: The role of and the percentage of (i) foreign sales on the total turnover and (ii) $\mathrm{R} \& \mathrm{D}$ expenditure on the total turnover, to control the Foreign Sales and R\&D expenditures (Terjensen and Patel, 2017; Trantopoulos et al., 2017). Moreover, we added Business Model (BM) Innovation as a further control variable. This was operationalized asking firms if the innovation brought by Industry 4.0 changed their business model (dummy 0/1), thus the strategic and organizational procedures through which firms generate value (Pucci, 2016).

\section{Findings}

Table 3 outlines the descriptive statistics and Pearson's correlation among dependent, independent, and control variables. The correlation indicators do not reveal problems in terms of multicollinearity, as confirmed by low VIF scores and high Tolerance for all variables, see Table 4 .

Tab. 3: Descriptive statistics and correlations

\begin{tabular}{|l|l|c|c|c|c|c|c|c|c|c|c|}
\hline & & {$[1]$} & {$[2]$} & {$[3]$} & {$[4]$} & {$[5]$} & {$[6]$} & {$[7]$} & {$[8]$} & {$[9]$} & {$[10]$} \\
\hline$[1]$ & Process Innovation & 1,000 & & & & & & & & & \\
\hline$[2]$ & Age (log) & 0,117 & 1,000 & & & & & & & & \\
\hline$[3]$ & Size $(\log )$ & 0,092 & 0,481 & 1,000 & & & & & & & \\
\hline$[4]$ & Foreign sales (\%) & 0,242 & 0,223 & 0,405 & 1,000 & & & & & & \\
\hline$[5]$ & R\&D Expend. (\%) & 0,122 & $-0,365$ & $-0,070$ & 0,278 & 1,000 & & & & & \\
\hline$[6]$ & Busin. Model Innovat. & 0,333 & $-0,029$ & 0,171 & 0,041 & 0,052 & 1,000 & & & & \\
\hline$[7]$ & Resources 4.0 & 0,374 & 0,165 & 0,298 & 0,144 & 0,110 & 0,287 & 1,000 & & & \\
\hline$[8]$ & $\begin{array}{l}\text { Stimuli 4.0 from SC } \\
\text { (Upstream) }\end{array}$ & 0,152 & 0,181 & 0,307 & 0,272 & 0,131 & 0,204 & 0,280 & 1,000 & & \\
\hline$[9]$ & $\begin{array}{l}\text { Stimuli 4.0 from SC } \\
\text { (Downstream) }\end{array}$ & 0,169 & 0,125 & 0,128 & 0,198 & 0,066 & 0,367 & 0,154 & 0,344 & 1,000 & \\
\hline$[10]$ & $\begin{array}{l}\text { Stimuli } 4.0 \text { from SC } \\
\text { (Horizontal) }\end{array}$ & $-0,012$ & 0,221 & 0,331 & 0,199 & 0,077 & 0,157 & 0,143 & 0,481 & 0,457 & 1,000 \\
\hline & Mean & 0,400 & 2,819 & 3,475 & 0,355 & 0,082 & 0,426 & 0,232 & 3,388 & 2,597 & 2,841 \\
\hline & Std. Dev. & 0,244 & 1,021 & 1,880 & 0,351 & 0,106 & 0,497 & 0,186 & 0,948 & 0,934 & 0,930 \\
\hline & Min & 0,000 & 0,000 & 0,000 & 0,000 & 0,000 & 0,000 & 0,000 & 1,000 & 1,000 & 1,000 \\
\hline & Max & 1,000 & 4,248 & 8,497 & 1,000 & 0,800 & 1,000 & 0,700 & 5,000 & 5,000 & 4,500 \\
\hline
\end{tabular}

Note: $\mathrm{N}=115$; Correlation coefficients greater than 0,198 in absolute value are statistically significant at $95 \%$.

Source: Our elaboration 
sinergie

Vol. 37, Issue 2, 2019

Tab. 4: VIF scores and tolerance

\begin{tabular}{|l|l|l|}
\hline & VIF scores & Tolerance \\
\hline Age $(\log )$ & 1,66 & 0,60 \\
\hline Size $(\log )$ & 1,72 & 0,58 \\
\hline Foreign sales (\%) & 1,45 & 0,69 \\
\hline R\&D Expend. (\%) & 1,44 & 0,70 \\
\hline Busin. Model Innovat. & 1,30 & 0,77 \\
\hline Resources 4.0 & 1,24 & 0,81 \\
\hline Stimuli 4.0 from SC (Upstream) & 1,47 & 0,68 \\
\hline Stimuli 4.0 from SC (Downstream) & 1,50 & 0,67 \\
\hline Stimuli 4.0 from SC (Horizontal) & 1,60 & 0,63 \\
\hline
\end{tabular}

Note: Mean VIF 1, 49; Condition number: 16, 366

Source: Our elaboration

In order to investigate the relationship between Process Innovation and Resources 4.0, as mediated by Stimuli 4.0 from SC, we employed a linear regression analysis. Table 5 shows the results of the hierarchical regression divided in 6 tested models: in Model A, we entered only control variables; in Model B, we introduced the main effect; in Model C, we inserted the moderating variables; from Model D to $\mathrm{F}$, we introduced interaction terms.

Tab 5: Linear Regression Results

\begin{tabular}{|l|l|l|l|l|l|l|}
\hline & Mod. A & Mod. B & Mod. C & Mod. D & Mod. E & Mod. F \\
\hline Age (log) & 0,043 & 0,034 & 0,037 & 0,038 & 0,038 & 0,042 \\
\hline & 0,027 & 0,027 & 0,028 & 0,029 & 0,028 & 0,028 \\
\hline Size (log) & $-0,017$ & $-0,026^{*}$ & $-0,021$ & $-0,021$ & $-0,022$ & $-0,018$ \\
\hline & 0,013 & 0,012 & 0,013 & 0,013 & 0,014 & 0,013 \\
\hline Foreign sales (\%) & $0,148^{*}$ & $0,155^{*}$ & $0,150^{*}$ & $0,149^{*}$ & $0,152^{*}$ & $0,145^{*}$ \\
\hline & 0,072 & 0,069 & 0,071 & 0,072 & 0,071 & 0,068 \\
\hline R\&D Expend. (\%) & 0,233 & 0,117 & 0,154 & 0,154 & 0,134 & 0,261 \\
\hline & 0,185 & 0,172 & 0,181 & 0,182 & 0,191 & 0,201 \\
\hline Busin. Model Innovat. & $0,171^{* * *}$ & $0,135^{* *}$ & $0,135^{* *}$ & $0,136^{* *}$ & $0,134^{* *}$ & $0,141^{* *}$ \\
\hline & 0,045 & 0,045 & 0,047 & 0,047 & 0,048 & 0,046 \\
\hline Resources 4.0 & & $0,385^{* * *}$ & $0,376^{* *}$ & 0,109 & 0,587 & $-0,737$ \\
\hline & & 0,111 & 0,119 & 0,475 & 0,443 & 0,475 \\
\hline Stimuli 4.0 from SC (Upstream) & & & 0,008 & $-0,006$ & 0,006 & 0,025 \\
\hline & & & 0,026 & 0,038 & 0,026 & 0,028 \\
\hline Stimuli 4.0 from SC (Downstream) & & & 0,010 & 0,011 & 0,027 & 0,016 \\
\hline & & & 0,031 & 0,030 & 0,051 & 0,032 \\
\hline Stimuli 4.0 from SC (Horizontal) & & & $-0,042$ & $-0,039$ & $-0,043$ & $-0,123^{*}$ \\
\hline & & & 0,034 & 0,035 & 0,034 & 0,053 \\
\hline Resources 4.0 X Stimuli 4.0 from SC (Upstream) & & & & 0,075 & & \\
\hline & & & & 0,129 & & \\
\hline Resources 4.0 X Stimuli 4.0 from SC (Downstream) & & & & & $-0,077$ & \\
\hline & & & & & 0,150 & \\
\hline Resources 4.0 X Stimuli 4.0 from SC (Horizontal) & & & & & & $0,369^{*}$ \\
\hline & & & & & & 0,147 \\
\hline Constant & $0,194^{*}$ & $0,183^{*}$ & $0,22^{*}$ & $0,256^{*}$ & 0,190 & $0,352^{* *}$ \\
\hline & 0,078 & 0,075 & 0,098 & 0,116 & 0,120 & 0,110 \\
\hline & & & & & & \\
\hline R2 & 0,188 & 0,260 & 0,276 & 0,278 & 0,278 & 0,314 \\
\hline Adj. R2 & 0,151 & 0,218 & 0,214 & 0,208 & 0,208 & 0,248 \\
\hline
\end{tabular}

Note: $\mathrm{N}=115 ;{ }^{*} \mathrm{p}<0.05 ;{ }^{* *} \mathrm{p}<0.01 ;{ }^{* *} \mathrm{p}<0.001$

Source: Our elaboration 
For what concerns control variables, both Age and R\&D expenditures are not significant in all models, while Size is significant at $10 \%$ only in Model B, but its magnitude is almost negligible. On the other hand, Foreign Sales and BM innovation show a positive and significant impact on PI in all models, respectively at $10 \%$ and $5 \%$ levels.

For what concerns Hp.1, Model B confirms a positive and significant effect of Resources 4.0 on Process Innovation (at 1\% level). This effect is almost the double in magnitude if compared to Foreign Sales and BM Innovation. Additionally, Model $\mathrm{C}$ suggests that there is not a direct effect of Stimuli 4.0 from SC on PI, and this is true regardless of the source.

For what concerns Hp. 2, both Model D and E show an insignificant interaction term, thus upstream and downstream sources are not able to moderate the relationship among Resources 4.0 and Process Innovation. On the other hand, Horizontal sources are able to act as moderators, as shown in Model F. Consequently, Competitors, Universities, Consultants, and Technological Transfer Offices can enhance the ability of Resources 4.0 to bring PI in firms. Therefore, we can conclude that Hp. 2 is partially supported.

Given the magnitude and significant levels of both BM innovation and the interaction term Resources 4.0 X Horizontal stimuli we conducted the post-hoc analysis shown in Figure 5. What emerges from the interaction among resources, horizontal stimuli, and business model is that firms, not introducing changes in their business model, are less able to gather advantages from both resources 4.0 held and horizontal stimuli received. Therefore, to adapt and change both organizational and strategic procedures it seems fundamental to obtain higher PI results.

Fig. 5: Three-way interaction among Resources 4.0, Horizontal stimuli, and BM innovation

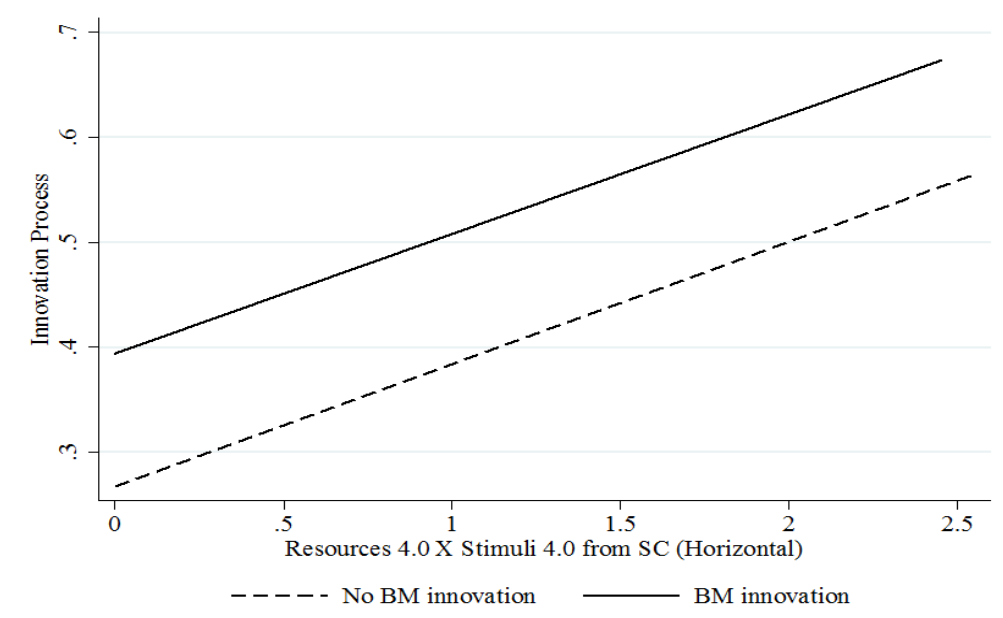

Niccolò Fiorini Matteo Devigili Tommaso Pucci Lorenzo Zanni Managing resources and innovation inside the industry (Industrial) 4.0 Revolution: The role of Supply Chain 


\section{sinergie}

Vol. 37, Issue 2, 2019

\section{Discussion and conclusions}

This research points out three main results. Firstly, resources 4.0 have a positive impact on firms' PI. Hence, following the RBV perspective, the procurement and development of resources 4.0 enhances the competitive advantage of firms fostering PI. Secondly, our panel of respondent reveals that the positive relationship among resources 4.0 and PI is nurtured by horizontal partners (such as University, Consultant, etc.), rather than from upstream or downstream actors. However, we should highlight how these results may be affected by both sample composition and the timing of data collection. For what concerns the former, our sample is largely composed by medium and large companies (more than $40 \%$ of the interviewed). Indeed, their behaviour is different from the micro and small ones, since they have more public sector linkages (Rothwell and Dodgson, 1991) especially for technical inputs. Moreover, the SC sees the involvement of two main actors: the broker, pushing for the I4.0 introduction in SC, and the receiver, adapting to technological changes required from brokers. While the first are usually larger companies, the second are usually smaller subcontractors. For what concerns the timing of data collection, since the sample is mainly composed by Italian manufacturing firms (73\%), we should take into account that the Italian 4.0 plan was introduced only in 2016. Therefore, given the initial stage of the Italian I4.0 and the complexity and abstraction level required for the I4.0 implementation, firms may be searching for stimuli from Universities, consultants and horizontal partners in general. Indeed, being at the early stage of I4.0, the competencies linked with resources 4.0 mainly come from Universities, research centres and specialised experts. Therefore, we expect a different relationship among 4.0 stimuli and PI in future I4.0 stages of implementation. Thirdly, from the post-hoc analysis emerges that firms can obtain higher PI results if they combine the exploitation of horizontal 4.0 stimuli with changes on BM. In general, the adoption of new and distinctive resources lays the foundations for the whole business model reconfiguration inside firms (Morris et al., 2005), thus enhancing efficacy and efficiency of value creation, provision, and capture (Amit and Zott, 2001; Venkatraman and Henderson, 1998; Pucci et al., 2013; Pucci et al., 2017). Additionally, the literature underlines how new technologies, or existing technologies applied for other purposes (Casprini et al., 2014), may enable the appearance of new BMs (BadenFuller and Haefliger, 2013; Teece, 2010; Zott et al., 2011; Baden-Fuller and Mangematin, 2013; Casprini, 2015; Teece, 2017). Indeed, companies will be asked soon to compete on quickness in delivery, execution of processes and decision making (Atti, 2018a), therefore the exploitation of I4.0 resources will be crucial to develop an adequate and competitive BM. Therefore, our findings confirm resources ability - in this case 4.0 resources - to impact on the BM outline, thus influencing how companies are organised and how they deal with suppliers, partners and competitors (Prause, 2015; Bauer et al., 2014; Russo, 2018).

This paper contributes both to the academic and the non-academic literature thanks to its integration of scholars' knowledge and the expertise of a renewed national association of procurement and supply chain 
management (ADACI). Moreover, there are several implications also from a managerial point of view. First, this study shows the importance for companies to be at the forefront of technological adoption, following the I4.0 paradigm, since this will turn in a positive influence for PI. Second, it demonstrates to managers and companies the importance of horizontal chains, as also pointed out in the literature by Lin et al. (2017), e.g. the connections with universities and consultants. Hence, when we are at an early stage of technological introduction companies rely more on external providers which already have available these technologies to close the gap as soon as possible. This is definitely true, considering the size of the companies in our sample, for medium and big size companies, which are in turn those usually acting as leaders for the whole chain. Moreover, managers should consider that BM changes allow companies to obtain higher PI results than the ones gained thanks to resources 4.0 and/or external stimuli 4.0 alone. This will allow all the companies to benefit both from (internal) adoption of I4.0 technologies and from external influences of the SC, with a special role played by horizontal partners with whom companies should always collaborate.

Considering the results about the impact of I4.0 on the players of the SC both directly, thanks to the positive impact of I4.0 technologies adoption within the companies, and indirectly, as well as the results about the positive horizontal influence of technologies 4.0, for what concerns the theoretical contribution, we can enlighten the comprehensive impact of I4.0 for the whole chain: the technology linked with the I4.0 paradigm has an effect in the whole chain, both directly and indirectly.

It is interesting to point out that this research signals which actors need to be supervised in further studies, as also pointed out by Lin et al. (2017) in their study about China and Taiwan: the horizontal partners.

In conclusion being, to the best of our knowledge, the first one on this topic, this study contributes in developing the current report-based knowledge with an empirical study based on an experts' survey. Moreover, the results showing the impact of resources 4.0 and PI, the drivers of innovation in SC4.0 as well as the effects on BM represent a first impulse to further analysis on these topics.

There are several limitations in this study. First, the sample of this study is limited to Italian companies, thus it would be extremely fruitful to extend the survey to other countries. Indeed, a comparison between the current maturity level of I4.0 and the policies in the Italian context with other countries would be extremely interesting both from a practical and an academic point of view. Second, we analysed the Italian context at an early stage, while a replication of this study later on will allow a comparison of different maturity stages within the same country and additionally a better analysis of the effects of Piano Nazionale 4.0, leading to significant and stimulating discussions both for scholars and practitioners.

Third, due to the small size of our sample, this paper may be threatened by biases regarding sample characteristics. Further studies based upon similar RQs, might offer interesting and stimulating results to the audience.
Niccolò Fiorini

Matteo Devigil

Tommaso Pucci

Managing resources and innovation inside the

industry (Industrial) 4.0 Revolution: The role of Supply Chain 


\section{sinergie}

Vol. 37, Issue 2, 2019

\section{References}

AMIT R., ZOTT C. (2001), "Value creation in e-business", Strategic Management Journal, vol. 11, n. 22, pp. 493-520.

ARDiTO L., PETRUZZELLI A.M., PANNIELLO U., GARAVELLI A.C. (2018), "Towards Industry 4.0: Mapping digital technologies for supply chain management-marketing integration", Business Process Management Journal, vol. 25, n. 2 pp. 323-346.

ARMSTRONG C.E., SHIMIZU K. (2007), "A review of approaches to empirical research on the resource-based view of the firm", Journal of Management, vol. 33, n. 6, pp. 959-986.

ARORA A., GAMBARDELLA A. (1994), "Evaluating technological information and utilizing it: Scientific knowledge, technological capability, and external linkages in biotechnology", Journal of Economic Behavior and Organization, vol. 24, n. 1, pp. 91-114.

ATTI G. (2018a), "L'impresa intelligente e la rivoluzione digitale", in Atti G., (a cura di), La quarta rivoluzione industriale: verso la supply chain digitale. Il futuro degli acquisti pubblici e privati nellera digitale. Casi e studi d'impresa, Franco Angeli Edizioni, Milano.

ATTI G. (2018b), "La supply chain digitale e gli acquisti del futuro", in Atti G., (a cura di), La quarta rivoluzione industriale: verso la supply chain digitale. Il futuro degli acquisti pubblici e privati nell'era digitale. Casi e studi d'impresa, Franco Angeli Edizioni, Milano.

BADEN-FULLER C., HAEFLIGER S. (2013), "Business models and technological innovation”, Long Range Planning, vol. 46, n. 6, pp. 419-426.

BADEN-FULLER C., MANGEMATIN V. (2013), "Business models: a challenging agenda", Strategic Organization, vol. 11, n. 4, pp. 418-427.

BARNEY J.B. (1991), "Firm resources and sustained competitive advantage", Journal of Management, vol. 17, n. 1, pp. 99-120.

BARNEY J.B. (2001), "Is the resource-based "view" a useful perspective for strategic management research? Yes", Academy of Management Review, vol. 26, n. 1, pp. 41-56.

BARRETO L., AMARAL A., PEREIRA T. (2017), "Industry 4.0 implications in logistics: an overview", Procedia Manufacturing, vol. 13, n. 17, pp. 1245-1252.

BAUER W., SCHLUND S., MARRENBACH D., GANSCHAR O. (2014), Industry 4.0 - VolkswirtschaftlichesPotenzialfür Deutschland, BITKOM, Berlin.

BAUR C., WEE D. (2015), Manufacturing's next act, McKinsey and Company, Munich.

BEN-DAYA M., HASSINI E., BAHROUN Z. (2017), "Internet of things and supply chain management: a literature review", International Journal of Production Research, vol. 57, n. 16, pp. 4719-4742.

BERTINI S. (2017), Il posizionamento tecnologico delle supply chain toscane sul tema fabbrica 4.0, Irpet, Firenze.

BIENHAUS F., HADDUD A. (2018), "Procurement 4.0: factors influencing the digitisation of procurement and supply chains", Business Process Management Journal, vol. 24, n. 4, pp. 965-984.

BIDET-MAYER T., CIET N. (2016), L'industrie du futur: une compétition mondiale, La Fabrique de l'Industrie, Presses des Mines, Paris. 
BITTIGHOFER D., DUST M., IRSLINGER A., LIEBICH M., MARTIN L. (2018), "State of Industry 4.0 Across German Companies", in AA.VV., System Sciences, 2018 IEEE International Conference on Engineering, Technology and Innovation (ICE/ITMC), IEEE, Stuttgart.

BOGERS M., HADAR R., BILBERG A. (2016), "Additive manufacturing for consumer goods manufacturing", Technological Forecasting and Social Change, vol. 102, n. 2016, pp. 225-239.

BUCY M., HALL S., YAKOLA D. (2016), Transformation with a Capital T, McKinsey Quarterly, Charlotte.

BUTNER K. (2010), "The smarter supply chain of the future", Strategy and Leadership, vol. 38, n. 1, pp. 22-31.

CALOGHIROU Y., KASTELLI I., TSAKANIKAS A. (2004), "Internal capabilities and external knowledge sources: complements or substitutes for innovative performance?", Technovation, vol. 24, n. 1, pp. 29-39.

CANTNER U., JOEL K., SCHMIDT T. (2011), "The effects of knowledge management on innovative success - An empirical analysis of German firms", Research Policy, vol. 40, n. 10, pp. 1453-1462.

CARBONNEAU R., LAFRAMBOISE K., VAHIDOV R. (2008), "Application of machine learning techniques for supply chain demand forecasting", European Journal of Operational Research, n. 184, pp. 1453-1462.

CARLILE P. R. (2004), "Transferring, translating, and transforming: An integrative framework for managing knowledge across boundaries", Organization Science, vol. 15, n. 5, pp. 555-568.

CASPRINI E., PUCCI T., ZANNI L. (2014), "Business model shifts: a case study on firms that apply high-technology to cultural goods", Technology Analysis and Strategic Management, vol. 26, n. 2, pp. 171-187.

CASPRINI E. (2015), "Business model innovation: a typology", Sinergie Italian Journal of Management, vol. 33, n. 97, pp. 181-197.

CHEN I.J., PAULRAJ A. (2004), “Towards a theory of supply chain management: the constructs and measurements", Journal of Operations Management, vol. 22, n. 2, pp. 119-150.

DALENOGARE L.S., BENITEZ G.B., AYALA N.F., FRANK A.G. (2018), "The expected contribution of Industry 4.0 technologies for industrial performance", International Journal of Production Economics, vol. 204, n. 2018, pp. 383-394.

DI STEFANO G., GAMBARDELLA A., VERONA G. (2012), “Technology push and demand pull perspectives in innovation studies: Current findings and future research directions", Research Policy, vol. 41, n. 8, pp. 1283-1295.

DING B. (2018), "Pharma industry 4.0: Literature review and research opportunities in sustainable pharmaceutical supply chains", Process Safety and Environmental Protection, vol. 119, n. 2018, pp. 115-130.

DRATH R., HORCH A. (2014), “Industrie 4.0: Hit or hype?", IEEE Industrial Electronics Magazine, vol. 8, n. 2, pp. 56-58.

FANTONI G., CERVELLI G., PIRA S., TRIVELLI L., MOCENNI C., ZINGONE R., PUCCI T. (2017a), Impresa 4.0: Siamo Pronti Alla Quarta Rivoluzione Industriale?, Towel Publishing S.r.l.s, Pisa.

FANTONI G., CERVELLI G., PIRA S., TRIVELLI L., MOCENNI C., ZINGONE R., PUCCI T. (2017b), Ecosistemi 4.0: Imprese, Società, Capitale Umano, Fondazione G. Brodolini, Roma. 


\section{sinergie}

Vol. 37, Issue 2, 2019

FERNÁNDEZ-MIRANDA S.S., MARCOS M., PERALTA M.E., AGUAYO F. (2017), "The challenge of integrating Industry 4.0 in the degree of Mechanical Engineering", Procedia Manufacturing, vol. 13, n. 2017, pp. 1229-1236.

FROHLICH M.T., WESTBROOK R. (2001), "Arcs of integration: an international study of supply chain strategies", Journal of Operations Management, vol. 19, n. 2, pp. 185-200.

GEBBERS R., ADAMCHUK V. I. (2010), "Precision agriculture and food security", Science, vol. 327 n. 5967, pp. 828-831.

GEISSBAUER R., VEDSO J., SCHRAUF S. (2016), Industry 4.0: Building the digital enterprise. Retrieved from PwC Website: https://www. pwc. com/gx/en/ industries/industries-4.0/landing-page/industry-4.0-building-your-digitalenterprise-april-2016. pdf.

GHOBAKHLOO M. (2018), "The future of manufacturing industry: a strategic roadmap toward Industry 4.0", Journal of Manufacturing Technology Management, vol. 29, n. 6, pp. 910- 936.

GRANT R.M. (1991), "The resource-based theory of competitive advantage: implications for strategy formulation", California Management Review, vol. 33, n. 3, pp. 114-135

HAIR J., BLACK W., BABIN B., ANDERSON R. (2010), Multivariate Data Analysis, Pearson Prentice Hall, Englewood Cliffs.

HALLDÓRSSON Á., HSUAN J., KOTZAB H. (2015), “Complementary theories to supply chain management revisited-from borrowing theories to theorizing", Supply Chain Management: An International Journal, vol. 20, n. 6, pp. 574-586.

HERMANN M., PENTEK T., OTTO B. (2016), "Design principles for industrie 4.0 scenarios", In AA.VV., System Sciences, 2016 49th Hawaii International Conference on System Sciences (HICSS), IEEE, Koloa.

HORST J., SANTIAGO F. (2018), "What can policymakers learn from Germany's Industrie 4.0 development strategy?", Inclusive and Sustainable Industrial Development Working Paper, n. 22.

HENNING K. (2013), Recommendations for implementing the strategic initiative INDUSTRIE 4.0, Forschungsunion, acatech.

KAGERMANN H., WAHLSTER W., HELBIG J. (2013), Securing the Future of German Manufacturing Industry: Recommendations for Implementing the Strategic Initiative INDUSTRIE 4.0 Final Report of the Industrie 4.0 Working Group, German National Academy of Science and Engineering (ACATECH), Berlin.

KANG H.S., LEE J.Y., CHOI S., KIM H., PARK J.H., SON J.Y., KIM B.H., NOH D.S. (2016), "Smart manufacturing: Past research, present findings, and future directions", International Journal of Precision Engineering and Manufacturing-Green Technology, vol. 3, n. 1, pp. 111-128.

KHAQQI K.N., SIKORSKI J.J., HADINOTO K., KRAFT M. (2018), “Incorporating seller/buyer reputation-based system in blockchain-enabled emission trading application", Applied Energy, vol. 209, n. 2018, pp. 8-19.

KERSTEN W., BLECKER T., RI C.M. (2015), "The Impact of Industry Supply Chain”, in Kersten W., Blecker T., Ringle C.M. (a cura di), Innovations and strategies for logistics and supply chains, in Proceedings of the Hamburg International Conference of Logistics (HICL), epubli. 
KEUPP M.M., PALMIÉ M., GASSMANN O. (2011), "Achieving subsidiary integration in international innovation by managerial "Tools", Management International Review, vol. 51, n. 2, pp. 213-239.

KOGUT B., ZANDER U. (1992), "Knowledge of the firm, combinative capabilities, and the replication of technology", Organization Science, vol. 3, n. 3, pp. 383-397.

KOVÁCS G., KOT S. (2016), "New logistics and production trends as the effect of global economy changes", Polish Journal of Management Studies, vol. 14, n. 2, pp. 115-126.

KREIPL S., PINEDO M. (2004), "Planning and scheduling in supply chains: an overview of issues in practice", Production and Operations Management, vol. 13, n. 1, pp.77-92.

KUMAR M., GRAHAM G., HENNELLY P., SRAI J. (2016), "How will smart city production systems transform supply chain design: a product-level investigation", International Journal of Production Research, vol. 54, n. 23, pp. 7181-7192.

LASI H., FETTKE P., KEMPER H. G., FELD T., HOFFMANN M. (2014), "Industry 4.0", Business and Information Systems Engineering, vol. 6, n. 4, pp. 239-242.

LEE C., LEE K., PENNINGS J. M. (2001), "Internal capabilities, external networks, and performance: a study on technology-based ventures", Strategic Management Journal, vol. 22, n. 6-7, pp. 615-640.

LI DA XU, ERIC L. XU, LING LI (2018) "Industry 4.0: state of the art and future trends", International Journal of Production Research, vol. 56, n. 8, pp. 29412962.

LIAO Y., DESCHAMPS F., LOURES E.D.F.R., RAMOS L.F.P. (2017), “Past, present and future of Industry 4.0-a systematic literature review and research agenda proposal", International Journal of Production Research, vol. 55, n. 12, pp. 3609-3629.

LIN K., SHYU J., DING K. (2017), "A cross-strait comparison of innovation policy under industry 4.0 and sustainability development transition", Sustainability, vol. 9, n. 5, pp. 786.

LÓPEZ LÓPEZ T., RANASINGHE D.C., HARRISON M., MCFARLANE D. (2012), "Adding sense to the Internet of Things", Personal and Ubiquitous Computing, vol. 16, n. 3, pp. 291-308.

LU Y. (2017), "Industry 4.0: A survey on technologies, applications and open research issues", Journal of Industrial Information Integration, vol. 6, n. 2017, pp. 1-10.

MAJEED A.A., RUPASINGHE T.D. (2017), "Internet of things (IoT) embedded future supply chains for industry 4.0: An assessment from an ERP-based fashion apparel and footwear industry", International Journal of Supply Chain Management, vol. 6, n. 1, pp. 25-40.

MASLARIĆ M., NIKOLIČIĆ S. MIRČETIĆ D. (2016), "Logistics response to the industry 4.0: the physical internet”, Open Engineering, vol. 6, n. 2016, pp. 511-517.

MORRIS M., SCHINDEHUTTE M., ALLEN J. (2005), "The entrepreneur's business model: toward a unified perspective", Journal of Business Research, vol. 58 , n. 6, pp. 726-735.

MÜLLER J.M., KIEL D., VOIGT K.I. (2018), "What drives the implementation of industry 4.0? The role of opportunities and challenges in the context of sustainability", Sustainability, vol. 10, n. 1, p. 247.
Niccolò Fiorini

Matteo Devigili

Tommaso Pucci

Lorenzo Zanni

Managing resources and

innovation inside

industry (Industrial) 4.0 Revolution: The role of Supply Chain 
NAKASUMI M. (2017), "Information Sharing for Supply Chain Management Based on Blockchain Technology", in AA.VV., System Sciences, 2017 IEEE $19^{\text {th }}$ Conference on Business Informatics (CBI), IEEE, Thessaloniki.

PEREIRA A.C., ROMERO F. (2017), "A review of the meanings and the implications of the Industry 4.0 concept", Procedia Manufacturing, vol. 13, n. 2017, pp. 1206-1214.

POPKOVA E.G., RAGULINA Y.V., BOGOVIZ A.V., (2019), ” Fundamental differences of transition to industry 4.0 from previous industrial revolutions", in Popkova E.G., Ragulina Y.V., Bogoviz A.V., Industry 4.0: Industrial Revolution of the $21^{\text {st }}$ Century, Springer, Cham.

PRAUSE G. (2015) "Sustainable business models and structures for Industry 4.0", Journal of Security and Sustainability Issues, vol. 5, n. 2, pp. 159-170.

PUCCI T. (2016), Il modello di business. Caratteri strutturali e dinamiche evolutive, WoltersKluwer/Cedam, Milano.

PUCCI T., NOSI C., ZANNI L. (2017), "Firm capabilities, business model design and performance of SMEs", Journal of Small Business and Enterprise Development, vol. 24, n. 2, pp. 222-241.

PUCCI T., SIMONI C., ZANNI L. (2013), "Modelli di business e strategie di marketing nelle medie imprese. La gestione della crisi tra continuità e cambiamento", Mercati e Competitività, n. 3, pp. 25-45.

ROSS D.F. (2016), Introduction to supply chain management technologies, Crc Press, Boca Raton.

ROTHWELL R., DODGSON M. (1991), "External linkages and innovation in small and medium-sized enterprises", R\&D Management, vol. 21, n. 2, pp. 125-138.

RÜßMANN M., LORENZ M., GERBERT P., WALDNER M., JUSTUS J., ENGEL P., HARNISCH M. (2015), "Industry 4.0: The future of productivity and growth in manufacturing industries", Boston Consulting Group, vol. 9, n. 1 , pp. 54-89.

RUSSO F.A. (2018), "Risultati delle Survey su Il futuro degli Acquisti", in Atti G., (a cura di), La quarta rivoluzione industriale: verso la supply chain digitale. Il futuro degli acquisti pubblici e privati nell'era digitale. Casi e studi d'impresa, Franco Angeli Edizioni, Milano.

SAHAY B.S., RANJAN J. (2008), "Real time business intelligence in supply chain analytics", Information Management and Computer Security, vol. 16, n. 1, pp. 24-48.

SCHRAUF S., BERTTRAM P. (2016), "Industry 4.0: How digitization makes the supply chain more efficient, agile, and customer-focused", Strategy and Pwc, vol. 9, n. 2016, pp. 1-32.

SCHMIDT R., MÖHRING M., HÄRTING R.C., REICHSTEIN C., NEUMAIER P., JOZINOVIĆ P. (2015), "Industry 4.0-potentials for creating smart products: empirical research results", in Abramowicz W., (a cura di), Business Information Systems. BIS 2015. Lecture Notes in Business Information Processing, Springer, Cham.

SUNG T.K. (2018), “Industry 4.0: A Korea perspective", Technological Forecasting and Social Change, vol. 132, n. 2018, pp. 40-45.

TEECE D. (2010), "Business models, business strategy and innovation”, Long Range Planning, vol. 43, n. 2-3, pp.172-194.

TEECE D. (2017), "Business Model and Dynamic Capabilities", Long Range Planning, vol. 51, n. 1, pp. 40-49. 
TERJESEN S., PATEL P.C. (2017), "In Search of Process Innovations: The Role of Niccolò Fiorini Search Depth, Search Breadth, and the Industry Environment", Journal of Matteo Devigili Management, vol. 43, n. 5, pp. 1421-1446.

TIAN F. (2016), "An agri-food supply chain traceability system for China based on RFID \& blockchain technology", in AA.VV., Service Systems and Service Management, 2016 13th International Conference on Service Systems and Service Management (ICSSSM) (ICSSSM), IEEE, Kunming.

TJAHJONO B., ESPLUGUES C., ARES E., PELAEZ G. (2017), "What does Industry 4.0 mean to Supply Chain?”, Procedia Manufacturing, vol. 13, n. 2017, pp. 1175-1182.

THAMES L., SCHAEFER D. (2016), "Software-defined cloud manufacturing for industry 4.0", Procedia CIRP, vol. 52 n. 2016, pp. 12-17.

THOMKE S., VON HIPPEL E. (2002), "Customers as innovators: a new way to create value", Harvard Business Review, vol. 80, n. 4, pp. 74-85.

TRANTOPOULOS K., VON KROGH G., WALLIN M.W., WOERTER M. (2017), "External knowledge and information technology: implications for process innovation performance", MIS Quarterly, vol. 41, n. 1, pp. 287-300.

VENKATRAMAN N., HENDERSON J.C. (1998), "Real strategies for virtual organizing”, Sloan Management Review, vol. 40, n. 1, pp. 33-48.

VEUGELERS R., CASSIMAN B. (1999), "Make and buy in innovation strategies: evidence from Belgian manufacturing firms", Research Policy, vol. 28, n. 1, pp. 63-80.

VISICH J.K., LI S., KHUMAWALA (2009) "Empirical evidence of RFID impacts on supply chain performance", International Journal of Operations and Production Management, vol. 29, n. 12, pp. 1290-1315.

VON HIPPEL E. (2007), "Horizontal innovation networks-by and for users", Industrial and Corporate Change, vol. 16, n. 2, pp. 293-315.

WAHL M. (2015), "Strategic Factor Analysis For Industry 4.0", Journal of Security and Sustainability Issues, vol. 5, n. 2, pp. 241-247.

WAMBA S.F., LEFEBVRE L.A., BENDAVID Y., LEFEBVRE É. (2008), "Exploring the impact of RFID technology and the EPC network on mobile B2B eCommerce: A case study in the retail industry", International Journal of Production Economics, vol. 112, n. 2, pp. 614-629.

WITKOWSKI K. (2017), "Internet of Things, Big Data, Industry 4.0-Innovative Solutions in Logistics and Supply Chains Management", Procedia Engineering, vol. 182, n. 2017, pp. 763-769.

ZHONG R.Y., NEWMAN S.T., HUANG G.Q., LAN S. (2016), "Big Data for supply chain management in the service and manufacturing sectors: Challenges, opportunities, and future perspectives", Computers and Industrial Engineering, vol. 101, n. 2016, pp. 572-591.

ZANNI L., PUCCI T. (2012), "Capacità interne, relazioni esterne e performance in un cluster emergente: un'analisi empirica nel settore Life Sciences", Atti del XXIV Convegno Annuale Sinergie, Lecce.

ZOTT C., AMIT R., MASSA L. (2011), “The business model: recent developments and future research", Journal of Management, vol. 37, n. 4, pp. 1019-1042. 


\section{sinergie}

Vol. 37, Issue 2, 2019

\section{Internet Websites}

https://hvm.catapult.org.uk;

https://www.adaci.it;

https://www.economie.gouv.fr;

http://www.ifpsm.org;

https://www.manufacturingusa.com;

https://www.mise.gov.it;

https://www.smartindustry.nl.

\section{Academic or professional position and contacts}

Niccolò Fiorini

Postdoctoral Researcher of Management

University of Siena - Italy

e-mail: niccolo.fiorini@unisi.it

Matteo Devigili

PhD Student of Management

University of Siena - Italy

e-mail: matteo.devigili@unisi.it

\section{Tommaso Pucci}

Assistant Professor of Management

University of Siena - Italy

e-mail: tommaso.pucci@unisi.it

\section{Lorenzo Zanni}

Full Professor of Management

University of Siena - Italy

e-mail: lorenzo.zanni@unisi.it

sinergie

italian journal of management

ISSN 0393-5108 DOI 10.7433/s109.2019.03 pp. $35-56$ 